\title{
Will Climate Change Cause Hurricanes Like Maria to Become More Common?
}

\author{
Ronald T Richards* \\ Universidad del Este, Carolina
}

Submission: June 29, 2018; Published: July 09, 2018

*Corresponding author: Ronald T. Richards, Universidad del Este, Highway \#190 km 1.8, Carolina, Puerto Rico, Email: richardsr1@suagm.edu

\section{Abstract}

Hurricane Maria, a category 4 storm devastated Puerto Rico on 20 September 2018. For most people, the power blackout lasted three or more months. With the electricity, all aspects of modern society such as telephones, Internet, radio stations, newspapers, first responders, food, water, propane, and gasoline became hard to get. The death toll is still being debated and will never be know exactly. When Hurricane Katrina hit New Orleans in 2005 most deaths were due to flooding when the levees failed. In Hurricane Maria more of the deaths are due to the collapse of the health care system. Many climate models predict that climate change will make powerful hurricanes more common, but this has yet to be proven.

Keywords: Hurricane Maria; Puerto Rico; Climate Change

\section{Introduction}

On 20 September 2017, Hurricane Maria, a category 4 storm hit Puerto Rico. At that time, I was teaching physics at four universities. I live in the San Juan suburb of Trujillo Alto and my house was without electricity for 105 days until 3 January 2018. Today, thousands of people in Puerto Rico do not have electricity and for those who do blackouts are common. Hurricane Maria hitting Puerto Rico was part of a hurricane season that included massive destruction in Texas and Florida. Unless you have lived through a similar experience, it is difficult to imagine what Puerto Rico was like in the weeks after the hurricane. If you did not have stockpiled in your house food, water, cash, gasoline, propane, and medicine these things were only available from your neighbors or in very limited quantities in the few stores that were open [1]. There was no telephone service and there were very few first responders to answer your call. For a week and a half after the storm I was a volunteer with the Municipal Emergency Management Office. The day after the storm they had no working generator and no communication with the vehicles that left the office. The instruction was return in 3 hours so that the people in the office knew that you were alive. And it was not only the lack of telephone service. Radio and television stations were going off the air. There were no newspapers, Internet, or postal service. For most people the only connection with the world was an AM radio operated with batteries. And the radio was filled with hospital administrators making a desperate plea for a truck load of Diesel. As this is being written in June of 2018 on my way to work there are stoplights that are not working and houses whose roof is blue tarp provided by the Federal Emergency Management Agency (FEMA). How many people died in Puerto Rico from Hurricane
Maria? The official answer is 64 and the government has stopped releasing mortality data. Nobody believes that the government data are valid. The news network CNN spoke to about 100 funeral homes and came up with 499. The New York Times newspaper puts the number near 1000. Traditionally in hurricanes, 90 percent of the deaths came from water and not winds. It appears that in Hurricane Maria, that a significant portion of the deaths were people with a preexisting medical condition who died from a health care system that did not have electricity, telecommunication or transportation.

Researchers from Harvard and other universities interviewed people at 3299 homes and did a survey on how many people died. Their conclusion was that between 20 September 2017 and the end of the year that 4645 more people died than the year before. The 95 percent confidence interval is very wide from 793 to 8498 persons. That means that 4000 or 5000 deaths have almost the same probability as the widely quoted figure of 4645 [1]. How many people died from Hurricane Maria? How many people died from Hurricane Katrina which hit New Orleans in 2005. "The answer my friend" to quote Nobel laureate Bob Dylan "is blowing in the wind." We will never know how many died in Hurricane Katrina or Maria. Often the death toll of Katrina is said to be around 1500. The deaths from Katrina were more due to flooding when the levees failed and flooded the city. The levees were designed by the United States Armey Corps of Engineers [2]. The deaths from Maria were more due to the collapse of the health-care system. In both hurricanes most of the deaths were elderly. In Puerto Rico, only the Institute of Forensic Sciences can attribute a death to the hurricane. The system is rigid and 
is guaranteed to systemically undercount deaths in a major emergency. In the San Juan metropolitan area, what was several weeks living without modern society, was several months in the mountainous center of the island where many roads were blocked by landslides. People could wait 6 hours to buy gasoline and then the hour of curfew would arrive, and they would lose their place in the line. There were lines hours long to obtain cash or visit the bank, supermarket, buy propane, or enter the pharmacy. Private universities reopened a month after the storm without electricity in the classrooms. Physics labs were modified to do experiments without electronic sensors. Students worked near the windows to have light. Doing a test, cellphones were used as flashlights. The public University of Puerto Rico system and public schools were slower to reopen.

In 1928 a category 5 hurricane hit the Caribbean and Florida. In Puerto Rico it is called San Felipe and in Florida, it is called Lake Okeechobee. The storm killed about 4000 people, mostly in Guadalupe and Florida. The social crisis after the hurricane of 1928 was different than today. It is estimated that less than 10 percent of much smaller population had electricity, telephone, or vehicles that used gasoline and Diesel. The transportation system included carts pulled by horses and oxen. People lived in houses with thatched roofs. In 1929 people were camped everywhere looking for scraps of wood and metal to rebuild their houses. Many people had not rebuilt before the economy collapsed in the Great Depression. Malnutrition was common in Puerto Rico in the 1930s. I have spoken to a man who in 1941 was below the minimum weight to join the United States Army. There is one bright side to Hurricane Maria. I am using data from more than 60 non-pumping observation wells to create a groundwater level index that covers the last 36 years. The goal is an index that is more representative than any single observation well. The good news is that the preliminary results are that Hurricane Maria is the largest recharge event in the last 36 years. Hurricane are born over the open ocean where the friction is very low. A hurricane is formed over warm water when the atmospheric conditions are just right. The damage from a hurricane is after it forms and then crosses from the ocean to the land. The rising concentration of carbon dioxide in the atmosphere will cause the Earth and its oceans to become warmer. Hurricanes are usually born in tropical waters but not directly over the equator and they then travel to higher latitudes. In the process they transport heat away from the equator. One hypothesis is that powerful hurricanes will become most common as the waters of the oceans get warmers. This is a reasonable hypothesis, but it is unproven. The oceans regulate the climate of our planet. A central question for climate change is how common will hurricanes like Maria be? Will they hit Puerto Rico once every 80 years or once every 8 years?

\section{References}

1. Ndema A, Missanjo E (2015) Tree Growth Response of Pinus oocarpa Along Different Altitudes in Dedza Mountain Forest Plantation. Agriculture, Forestry and Fisheries 4(1): 24 -28.
2. Braga EP, Zenni RD, Hay JD (2014) A New Invasive Species in South America: Pinus oocarpa Schiede ex Schltdl. BioInvasions Records 3(3): 207-211.

3. Dvorak W (2002) Pinus oocarpa Schiede ex Schltdl. In: Vozzo J (ed), Tropical Tree Seed Manual. U.S. Department of Agriculture, Forest Service, USA, pp. 899.

4. Gogoi BR, Sharma M, Sharma CL (2014) Ring width variations of Khasi pine (Pinus kesiya Royle ex Gordon) at breast height. Journal of the Indian Academy of Wood Science 11(1): 87-92.

5. Sousa VB, Cardoso S, Quilho T, Pereira H (2012) Growth rate and ring width variability of teak, Techna grandis (Verbenaceae) in an unmanaged forest in East Timor. International Journal of Tropical Biology and Conservation 60(1): 483-494.

6. Alteyrac J, Cloutier A, Ung CH, Zhang SY (2006) Mechanical properties in relation to selected wood characteristics of black spruce. Wood and Fiber Science 38(2): 229-237.

7. Missanjo E, Matsumura J (2016) Radial Variation in Tracheid Length and Growth Ring Width of Pinus kesiya Royle ex Gordon in Malawi. International Journal of Research in Agriculture and Forestry 3(1): 1321.

8. Sharma CL, Sharma M, Carter MJ (2013) Radial variation in fibre length and wood density of Melanorrhoea usitata Wall. The Indian Journal of Forestry 139(6): 518-520.

9. Hernandez RE, Koubaa A, Beaudoin M, Fortin Y (1998) Selected mechanical properties of fast-growing poplar hybrid clones. Wood Fiber Science 30(2): 138-147.

10. Kamala FD, Sakagami H, Oda K, Matsumura J (2013) Wood Density and Growth Ring Structure of Pinus patula Planted in Malawi, Africa. IAWA Journal 34(1): 61-70.

11. Hardcastle PD (1978) A preliminary Silvicultural classification of Malawi. Forest Research institute of Malawi, Zomba, Malawi.

12. Malata H, Ngulube ES, Missanjo E (2017) Specific Site Stem Volume Models for Pinus patula and Pinus oocarpa. International Journal of Forestry Research.

13.VSN International (2015) Genstat for Windows (18 th $^{\text {th }}$ edn.), VSN International, Hemel Hempstead, UK.

14. Adamopoulos S, Voulgaridis E (2002) Within tree variation in growth rate and cell dimensions in the wood of black locust (Robinia pseudoacacia). IAWA Journal 23(2): 191-199.

15. Sharma CL, Sharma M, Jamir L (2014) Radial variation in wood properties of plantation grown Terminalia myriocarpa Heurck and Muell-Arg in Nagaland, India. Research Journal of Recent Sciences 3(ISC-2013): $9-14$.

16.Zhu J, Nakano T, Hirakawa Y (2000) Effect of radial growth rate on selected indices for juvenile and mature wood of Japanese larch. Journal of Wood Science 46(6): 417-422.

17. Ladrach WE (1986) Control of wood properties in plantations. IUFRO Congr Ljubjana, Yugoslavia, pp. 369-381.

18. Zobel BJ, Sprague JR (1998) Juvenile Wood in Forest Trees. SpringerVerlag, Berlin Heidelberg.

19. Izekor DN, Fuwape JA, Oluyege AO (2010) Effects of density on variations in the mechanical properties of plantation grown Tectona grandis wood. Archives of Applied Science Research 2(6): 113-120. 
This work is licensed under Creative Commons Attribution 4.0 License

DOI: 10.19080/IJESNR.2018.13.555855
Your next submission with Juniper Publishers will reach you the below assets

- Quality Editorial service

- Swift Peer Review

- Reprints availability

- E-prints Service

- Manuscript Podcast for convenient understanding

- Global attainment for your research

- Manuscript accessibility in different formats

( Pdf, E-pub, Full Text, Audio)

- Unceasing customer service

Track the below URL for one-step submission https://juniperpublishers.com/online-submission.php 